\title{
Growth Trends of Green Chilli in Jaipur District and State of Rajasthan
}

\author{
Sonu Kala, Sonu Jain* and P.S. Shekhawat
}

Department of Agricultural Economics, S.K.N. College of Agriculture, SKNAU, Jobner, Jaipur, Rajasthan, India

*Corresponding author: sonujain.ageco@sknau.ac.in (ORCID ID: 0000-0002-1590-6177)

Received: $25-03-2020$

Revised: $20-07-2020$

Accepted: 26-08-2020

\begin{abstract}
Jaipur district occupies first position in area and production of green chilli (Capsicum annum) in the state of Rajasthan. The present investigation was undertaken to study about growth rates in area, production and productivity of green chilli in Jaipur district as well as Rajasthan state. The secondary data on area, production and productivity of green chilli were collected for Jaipur district and Rajasthan state for the period 2002-03 to 2016-17. Growth rates were estimated by using statistical tools like linear model, compound growth rate model and CAGR mathematic model for calculating annual growth rate. The results revealed that area and production of green chilli were estimated to be significantly positive but productivity was negative in the district of Jaipur and the state of Rajasthan as a whole for the period 200203 to 2016-17. Results were also found that the growth rates in area and production of green chilli were estimated to be significantly positive i.e. 6.93 and 3.88 per cent per annum respectively, and productivity was negative i.e. -4.46 per cent per annum in the Jaipur district, whereas, in Rajasthan state, area and production of green chilli were estimated to be significantly positive i.e. 8.00 and 1.64 per cent per annum, respectively, and productivity was negative i.e. -0.013 per cent per annum during the period 2002-03 to 2016-17. Therefore, the study recommends increasing the productivity of the green chilli mainly by developing improved varieties of green chilli suiting to the changing agro climatic conditions of the state.

Highlights

(0 Area and production of green chilli in Jaipur district increased at significant rate.

- Area and production of green chilli in Rajasthan state increased at significant rate but the productivity decreased.
\end{abstract}

Keywords: Growth rate, area, production, productivity, CAGR mathematic model

Green chilli is one of the most valuable crop of India which belongs to the solanaceae family. It is a crop of both tropical and sub-tropical areas which can be grown up to 2000 meter altitudes and requires a warm humid climate in Indian condition. Though, green chilli can be grown in many types of soil, well drained loamy soils rich in organic matter with soil $\mathrm{pH}$ range of 6-7 are best suited for its cultivation. Green chilli is believed to be originated in a native of South America and is widely distributed in all tropical and sub tropical countries including India. Although, it was introduced as a spice crop, it became popular in preparation and preservation of food and medical usage in pharmaceutical industry (Raju and Lukose, 1991). India is one of the leading chilli producing country of the world. There are more than fifty varieties grown in India broadly belonging to two species: Capsicum annum and Capsicum frutescens. The fruits of capsicum annum are mild because they are totally lacking in pungency or the pungency is limited to the seed only. The fruits of Capsicum frutescens are small, elongated,

How to cite this article: Kala, S., Jain, S. and Shekhawat, P.S. (2020). Growth Trends of Green Chilli in Jaipur District and State of Rajasthan. Economic Affairs, 65(3): 459-463.

Source of Support: None; Conflict of Interest: None 
conical, very pungent and are deep red in colour when ripe. In Rajasthan, Green chilli is grown in Jaipur, Sikar, Hanumangarh, Bundi, Alwar, Sawai modhopur and Bhilwara districts. Jaipur district is the major Green chilli growing district of Rajasthan. Jaipur district occupies the first place in area and production followed by Sikar. Area, production and productivity of Green chilli including green pepper was 19,90,423 hectare, 3,67,71,482 tonnes and $18,474.2 \mathrm{~kg} / \mathrm{hecate}$ in the world during the year 2018-19. Area, production and productivity of Green chilli was 3,77,000 hectare, 38,51,000 MT and 10.03 MT/hectare in India during the year 2018-19. In Rajasthan, area, production and productivity of green chilli was 5520 hectare, 16230 MT and 2.94 MT/hectare during the year 2016-17 (Source: India AgriStat). Jaipur district covered an area of 5131 hectares and produced 9660 MT green chilli during the year 2018-19 (Source: Directorate of Economics \& Statistics, Pant Krishi Bhawan, Jaipur). The present paper was undertaken with the objective to estimate the growth trends of green chilli in Jaipur district and state of Rajasthan.

\section{MATERIALS AND METHODS}

Jaipur district was purposively selected as it ranked first in area and production of green chilli during 2016-17 in the state.

The present study was based on secondary data and the required data on area, production and productivity of green chilli in the Jaipur district as well as in the Rajasthan state were collected from records of Agriculture Statistics Cell, Directorate of Economics and Statistics and Directorate of Agriculture, Pant Krishi Bhawan, Govt. of Rajasthan, Jaipur for the period from 2002-03 to 2016-17.

\section{Statistical tools}

Statistical tools like linear model, Compound Growth Rate Model and CAGR mathematic formula were used to analyze growth rates in area, production and productivity of green chilli in the study area.

\section{Simple linear function}

$$
Y_{t}=a+b t
$$

Where,

$Y_{t}=$ time series data on area/production/productivity at time ' $t$ '. $a \& b=$ parameters of the function to be estimated. $t=$ Time index $(t=1,2,3 \ldots \ldots \ldots n)$.

\section{Compound Growth Rate function}

$$
Y_{t}=a(1+r)^{t}
$$

Where,

$Y_{t}$ : Time series data on area/production/productivity at time $t ; a$ : parameter of the function to be estimated; $t$ : Time index $(t=1,2, \ldots . . n) ; r$ : Average compound growth rate per annum.

The annual compound growth rate is then computed as:

$$
\text { C.G.R. }(\%)=(\text { Antilog } b-1) \times 100
$$

\section{CAGR (Compound Annual Growth Rate) mathematical formula}

$$
\left(\frac{\text { Ending value }}{\text { Beginning }}\right)^{\frac{1}{\text { No. of year }-1}}
$$

\section{RESULTS AND DISCUSSION}

The estimates of growth rates pertained to the period from 2002-03 to 2016-17. The linear model has been fitted on the data of area of green chilli in Jaipur district. The area under green chilli had increased at the rate of about 6.93 per cent per annum during study period. This increase in growth rate was witnessed in the production which found 3.88 per cent per annum. The results are in conformity with the results of Jat (1992). However, the productivity has shown decreasing growth i.e. 4.46 per cent per annum. The Coefficient of determination $\left(\mathrm{R}^{2}\right)$ was estimated to be $0.61,0.39$ and 0.29 indicated that 61 percent, 39 percent and 29 percent of variation in area, production and productivity respectively was due to time variable. Growth rates in area, production and productivity of Green chilli in Jaipur district as well as in Rajasthan during the period 2002-03 to 2016-17 is presented in Table 1 and Figs. 1,2 and 3.

Compound Growth Rate model has been fitted on the data of area of green chilli in Rajasthan. The area under green chilli had increased at the rate of about 8 percent annually during study period. This increase in growth rate was witnessed in the 
Table 1: Growth rates in area, production and productivity of Green chilli in Jaipur district during the period 2002-03 to 2016-17 (Per cent per annum)

\begin{tabular}{llllll}
\hline Particulars & Growth rates & Standard error & $\begin{array}{l}\text { F value and its } \\
\text { significance }\end{array}$ & $\mathbf{R}^{2}$ & Growth models \\
\hline Area & $6.93^{* *}$ & 29.589 & $20.30^{* *}$ & 0.610 & Linear \\
Production & $3.88^{*}$ & 55.892 & $7.048^{*}$ & 0.391 & Linear (3MA) \\
Productivity & $-4.46^{*}$ & 41.433 & $5.319^{*}$ & 0.290 & Linear \\
\hline
\end{tabular}

** Significant at $1 \%$ level and * Significant at $5 \%$ level of significance.

Table 2: Growth rates in area, production and productivity of Green chilli in Rajasthan during the period 2002-03 to 2016-17 (Per cent per annum)

\begin{tabular}{llllll}
\hline Particulars & Growth rates & Standard error & $\begin{array}{l}\text { F value and its } \\
\text { significance }\end{array}$ & $\mathbf{R}^{2}$ & Growth models \\
\hline Area & $8.00^{* *}$ & 0.026 & $10.594^{* *}$ & 0.449 & Compound \\
Production & $1.64^{*}$ & 55.892 & 7.048 & 0.391 & Linear (3MA) \\
Productivity & -0.013 & - & - & - & CAGR mathematic formula \\
\hline
\end{tabular}

** Significant at $1 \%$ level and * Significant at $5 \%$ level of significance.

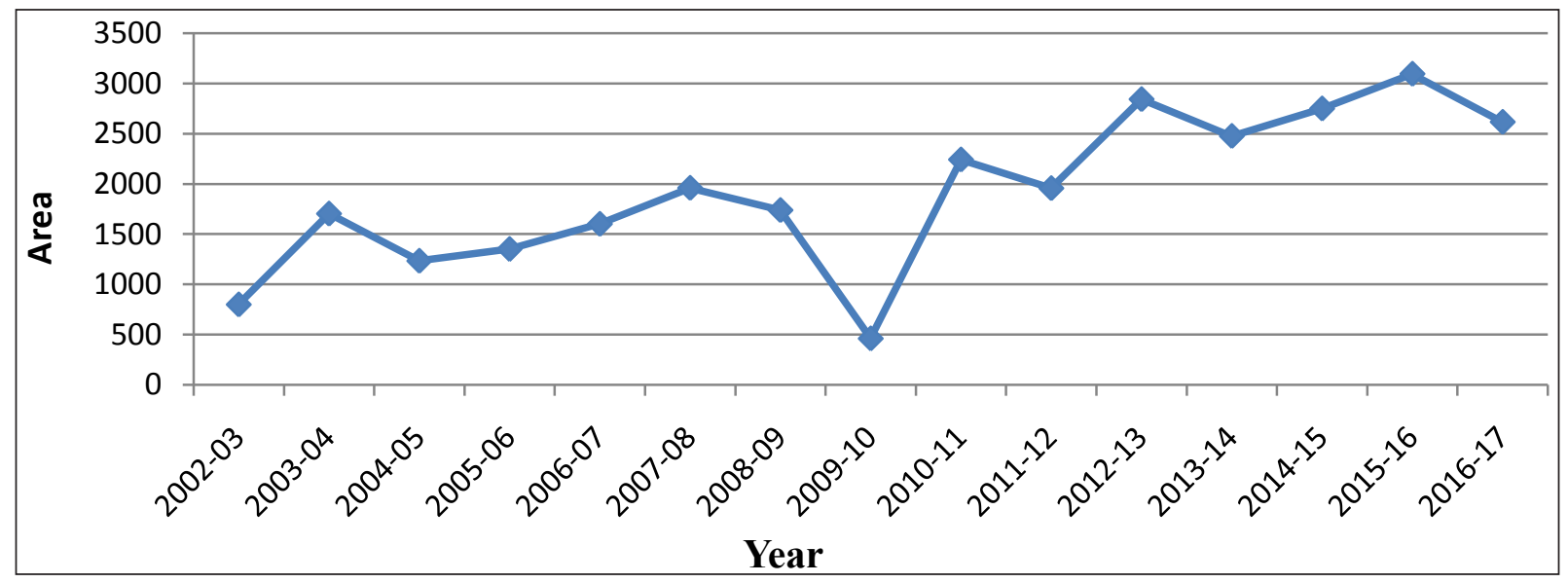

Fig. 1: Area (in hectare) of Green chilli in Jaipur district from 2002-03 to 2016-17

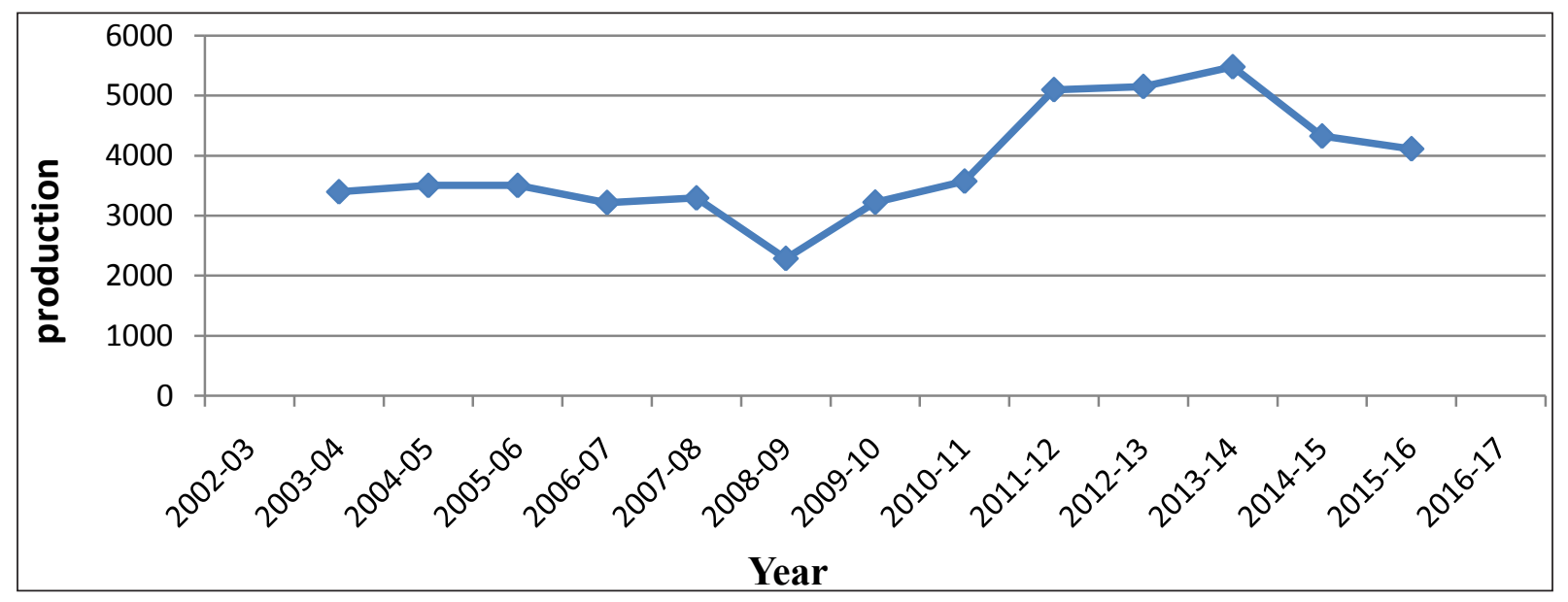

Fig. 2: Production (in MT) of Green chilli in Jaipur district from 2002-03 to 2016-17 


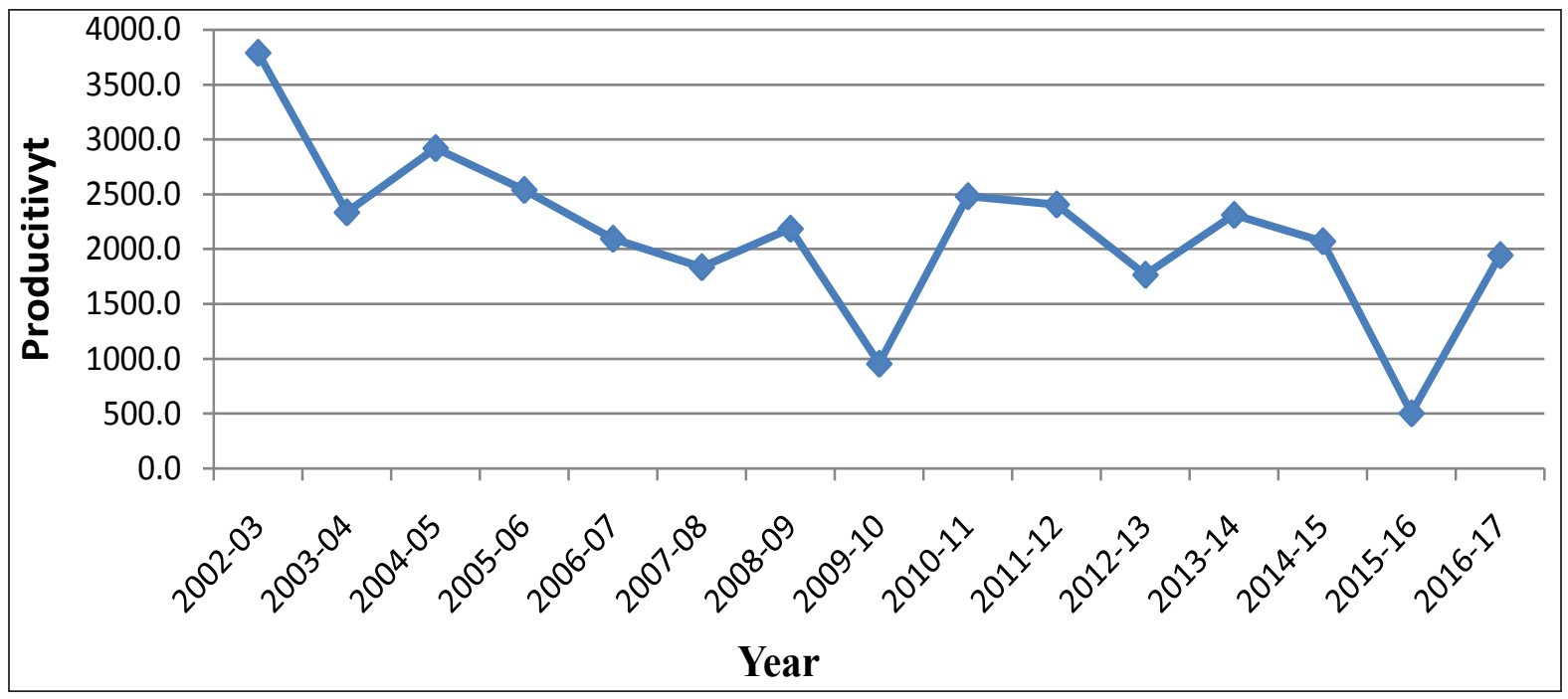

Fig. 3: Productivity (in q/ha) of Green chilli in Jaipur district from 2002-03 to 2016-17

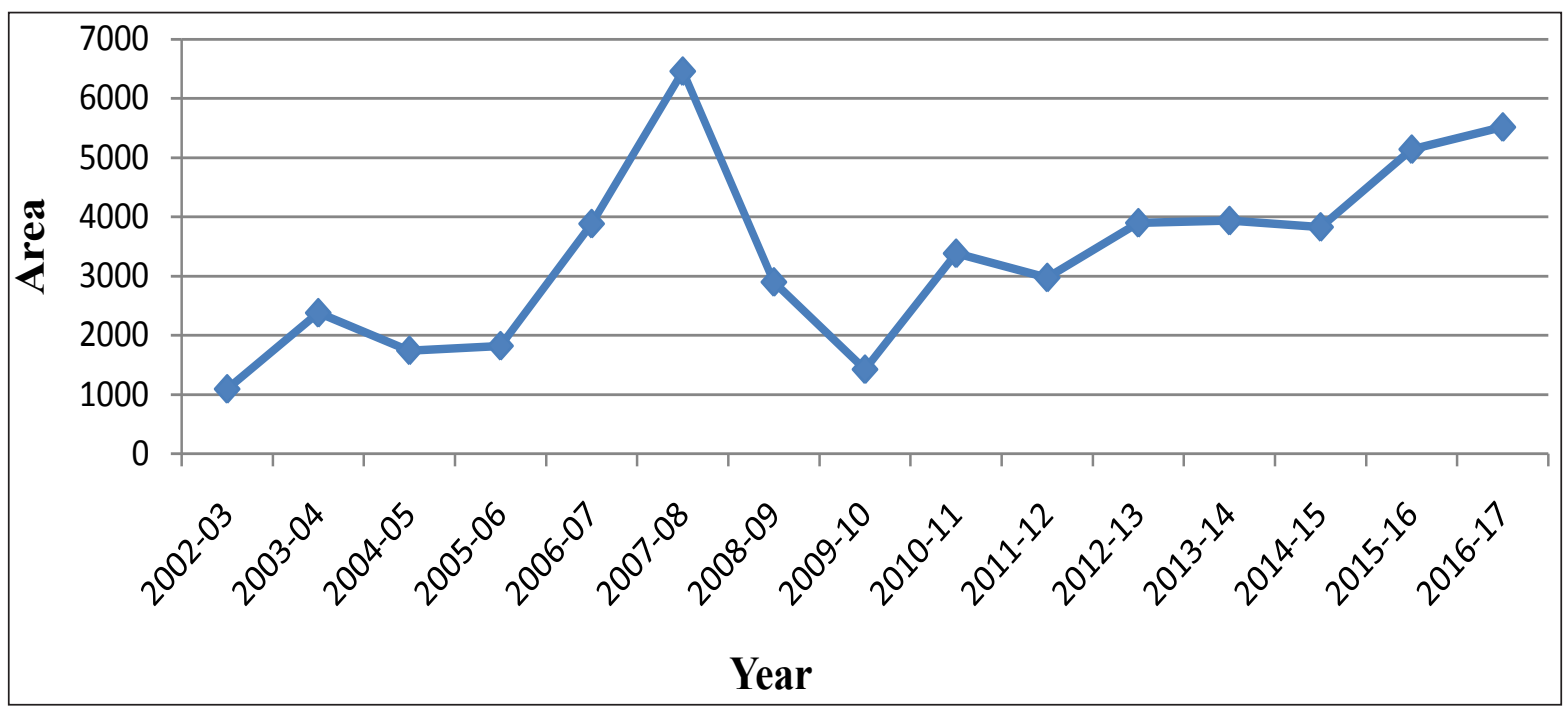

Fig. 4: Area (in hectare) of Green chilli in Rajasthan state from 2002-03 to 2016-17

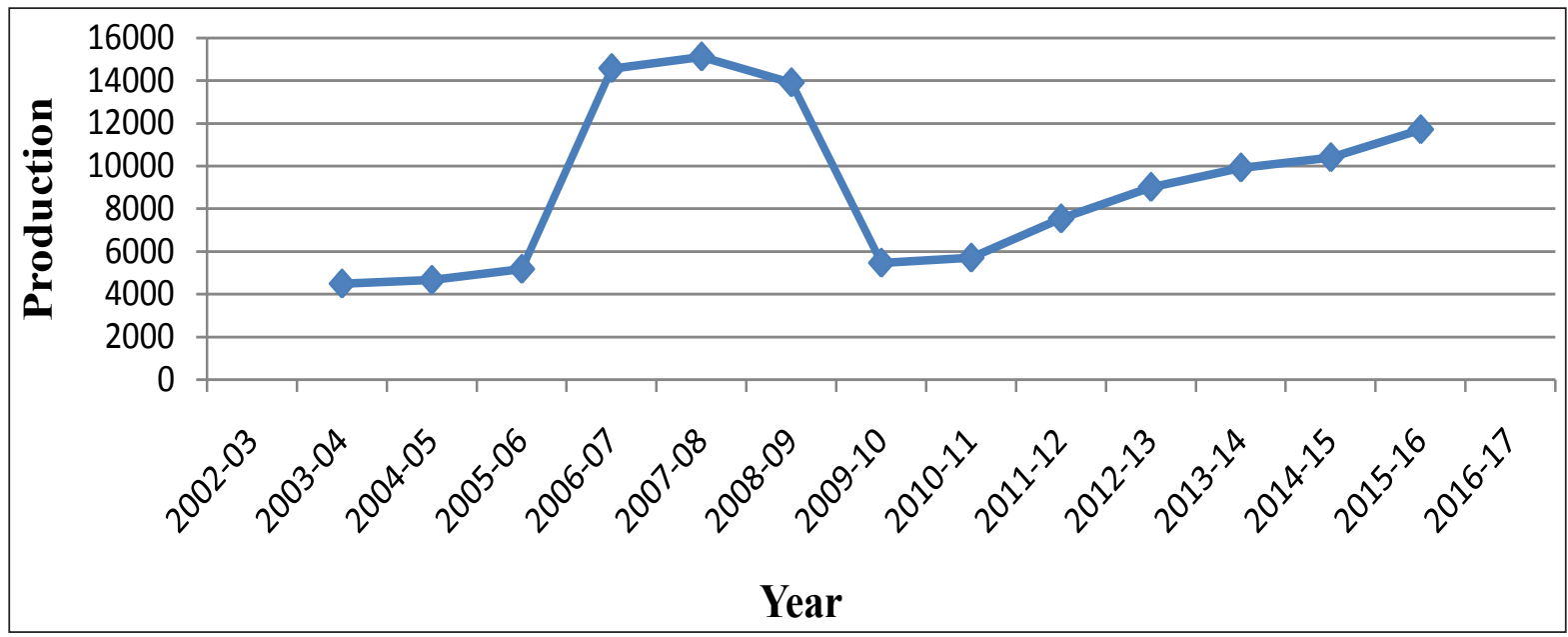

Fig. 5: Production (in MT) of Green chilli in Rajasthan state from 2002-03 to 2016-17 


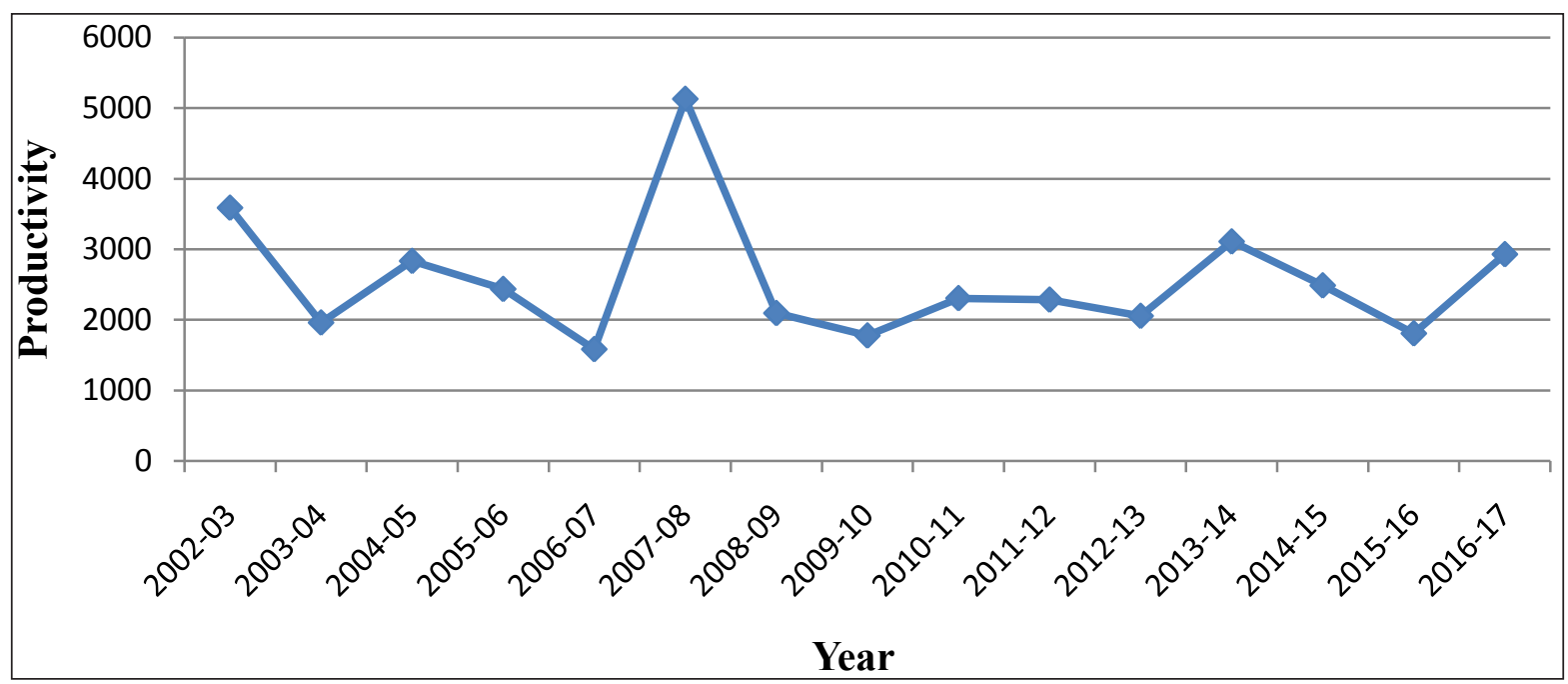

Fig. 6: Productivity (in q/ha) of Green chilli in Rajasthan state from 2002-03 to 2016-17

production which found 1.64 per cent per annum. The similar results were found out by Basavaraja C. Rajur (2007) and Hiremath (1994) and Bijarnia (1998). However, the productivity had shown decreasing growth i.e. 0.013 per cent per annum. Study was countered by Hiremath (1994) and Veeranagouda Goudra (2010). The Coefficient of determination $\left(\mathrm{R}^{2}\right)$ was 0.44 and 0.39 indicated that 44 per cent and 39 per cent of variation in area and production, respectively was due to time variable. Growth rates in area, production and productivity of Green chilli in Rajasthan during the period 200203 to 2016-17 is presented in Table 2 and Figs. 4, 5 and 6.

\section{CONCLUSIONS}

The above discussion leads to the clarity that the growth rates in area and production of green chilli were estimated to be significantly positive and productivity was negative in the Jaipur district and Rajasthan state during the period 2002-03 to 2016-17. To overcome these issues, there is a need to increase the productivity of the crop mainly by developing improved varieties of green chilli suiting to the changing agro climatic conditions of the state.

\section{REFERENCES}

Basavaraj, C. Rajur 2007. Production and Marketing Performance of Chilli in Karnataka- An Economic Analysis. Ph. D. Thesis. Department of Agricultural Economics, University of Agricultural Sciences, Dharwad (INDIA).

Bijarniya, S.K. 1998. An Economic Analysis of Onion Cultivation in Jaipur District of Rajasthan. M.Sc. Thesis. Department of Agricultural Economics, Rajasthan Agricultural University, Campus-Jobner, pp. 42-82.

Hiremath, A.P. 1999. Production and Marketing of Chillies in Karnataka-An Economic Analysis. M.Sc. (Agri) thesis (unpublished), University of Agricultural Sciences, Dharwad (INDIA).

Jat, J.P. 1992. Economic Analysis of Onion Cultivation in Jaipur District of Rajasthan. Unpublished M.Sc. (Ag.) Agril. Economics Thesis, Rajasthan Agricultural University, Bikaner, Campus Jobner, pp. 34-62.

Raju, K.V. and Lukose, C.K. 1991. Trends in Area, Production and Export of Chillies from India. Agricultural Situation in India, 45(11): 767-772.

Veeranagouda, G. 2010. Statistical Investigation of Price Behavior in Chilli. M.Sc. (Agri.) Thesis. University of Agricultural Sciences, Dharwad (INDIA). 